\title{
Proposal of Neotype Strains for Seven Non-Saccharolytic Bacteroides Species
}

\author{
ELIZABETH P. CATO, LILLIAN V. HOLDEMAN, AND W. E. C. MOORE \\ Anaerobe Laboratory, College of Agriculture and Life Sciences, Virginia Polytec. izic Institute and State \\ University, Blacksburg, Virginia 24061
}

The following strains are herein proposed as the neotype strains of their respective species: Bacteroides capillosus ATCC 29799, B. coagulans ATCC 29798, B. pneumosintes ATCC 33048, B. furcosus ATCC 25662, B. putredinis ATCC 29800, B. nodosus ATCC 25549, and B. praeacutus ATCC 25539.

Several species now classified in the genus Bacteroides have been well studied and described $(13,16)$, but no type or neotype strains have been designated to represent them. Among these are seven species of anaerobic, gram-negative, nonsporeforming, nonpigmenting, rodshaped, relatively non-saccharolytic organisms that have been isolated from the normal flora or clinical specimens from humans and other animals. Each of these species has characteristics that would permit it to be included in the genus Bacteroides as described in 1919 by Castellani and Chalmers (5) and emended in 1973 by Moore and Holdeman (20). However, the species have been placed in various other genera by other taxonomists.

For the species considered here, all of the strains on which the original descriptions were based have been lost. Therefore, we have selected strains whose characteristics agree with the characteristics first reported and propose that they be accepted as neotype strains of these species.

\section{MATERIALS AND METHODS}

Bacterial strains. B. capillosus ATCC 29799 (= VPI R2-29) was isolated in our laboratory from human feces. B. coagulans ATCC 29798 (= VPI $8755=$ EUH 581-73) was isolated from an infected perineal scar by D. W. Lambe, Jr., Emory University Hospital, Atlanta, Ga. B. pneumosintes ATCC $33048(=$ VPI $9515=\mathrm{Cal}$ 4692-1-74), isolated from an abscess in a nasal passage, was received from Genevieve Nygaard, California State Health Department, Berkeley. B. furcosus ATCC 25662 (= VPI $3253=$ Gifu T301A2) was isolated by S. Suzuki, Gifu University, Gifu-shi, Japan, from mud snails suspected of being involved in an outbreak of food poisoning. B. putredinis ATCC 29800 (= VPI 3293 = Gifu Ando) was isolated by $\mathrm{S}$. Suzuki from human feces. B. nodosus ATCC 25549 (= VPI 2340 $=$ Smith $11342=$ Beveridge 11342) was isolated by $\mathrm{W}$. I. B. Beveridge, McMaster Laboratory, Glebe, New South Wales, Australia, from an infected sheep hoof. B. praecutus ATCC 25539 (= VPI $0563=$ IPP 3722B) was isolated from a gangrenous lesion by A. R. Prévot, Pasteur Institute, Paris, France.
Culture media and methods. Except where otherwise indicated, reactions and characteristics of the proposed neotype strains were determined by using prereduced anaerobically sterilized media and anaerobic methods described in the Virginia Polytechnic Institute and State University Anaerobe Laboratory Manual (13). The basal broth medium used throughout contained, per $100 \mathrm{ml}, 0.5 \mathrm{~g}$ of peptone, $0.5 \mathrm{~g}$ of Trypticase, $1.0 \mathrm{~g}$ of yeast extract, $0.5 \mathrm{mg}$ of crystalline equine hemin, $0.1 \mu \mathrm{l}$ of vitamin $\mathrm{K}_{1}$ (Sigma), salts solution, resazurin, and cysteine. Tubes of media were inoculated under a stream of either oxygen-free $\mathrm{CO}_{2}$ or $90 \% \mathrm{~N}_{2}-10 \% \mathrm{CO}_{2}$. An atmosphere of $10 \% \mathrm{CO}_{2}-90 \%$ $\mathrm{H}_{2}$ was used for anaerobic incubation of plates.

Susceptibilities of the organisms to penicillin G, tetracycline, clindamycin, chloramphenicol, and erythromycin were tested by the broth disk method of W. kins and Thiel (34).

The guanine plus cytosine $(\mathrm{G}+\mathrm{C})$ contents of deoxyribonucleic acid (DNA) preparations from these strains were determined by J. L. Johnson by the thermal melting point method, as previously described $(15,19)$.

\section{RESULTS AND DISCUSSION}

Several characteristics were common to all of the proposed neotype strains. All were obligately anaerobic. None produced growth on blood agar plates (BAP) incubated aerobically or under $10 \%$ $\mathrm{CO}_{2}$. No brown- or black-pigmented colonies were observed on laked rabbit blood-brain heart infusion agar plates or streak tubes. Whole rabbit blood was not hemolyzed. No strain produced lecithinase or lipase on McClung-Toabe egg yolk agar plates. Cells of all strains were gram-negative rods. Spores were not formed, and no strain survived heating at $80^{\circ} \mathrm{C}$ for $10 \mathrm{~min}$. Growth of the organisms was inhibited by $20 \%$ bile and by $6.5 \% \mathrm{NaCl}$. Other characteristics of the proposed neotype strains are given below.

Bacteroides capillosus (Tissier) Kelly 1957 (17). [Synonyms: Bacillus capillosus Tissier 1908 (28); Ristella capillosa (Tissier) Prévot 1938 (25); Pseudobacterium capillosum (Tissier) Krasil'nikov 1949 (18).]

In 1908, Tissier described two strains he had 
isolated from the feces of infants (28). Neither of these strains is extant. ATCC 29799 was selected as the neotype strain of this species because it has the characteristics reported by Tissier and later authors $(16,26,28$; M. Sebald, $\mathrm{Ph} . D$. thesis, University of Paris, France, 1962). This strain also was isolated from human feces.

Cells of ATCC 29799 after $24 \mathrm{~h}$ of incubation at $37^{\circ} \mathrm{C}$ in peptone-yeast extract-glucose (PYG) broth were nonmotile rods with rounded ends, predominantly regular in shape, arranged singly, in pairs, or in short chains. The cells generally were 0.8 to 1.1 by 1.6 to $7.1 \mu \mathrm{m}$. Occasionally, shorter, slightly curved rods or filaments with tapered ends were seen, as described by Tissier in the original cultures (28).

Broth cultures were lightly turbid with a smooth sediment. Growth was stimulated by the addition of ca. $0.02 \%$ Tween 80 to the media. In $24 \mathrm{~h}$ there was good growth at 37 and $45^{\circ} \mathrm{C}$, only slight growth at $30^{\circ} \mathrm{C}$, and no growth at $25^{\circ} \mathrm{C}$.

Surface colonies on 48-h-old, anaerobic BAP were pinpoint to $0.5 \mathrm{~mm}$ in diameter, circular, slightly erose, colorless, translucent, and slightly peaked. No internal structure was visible.

Only traces of acetic and lactic acids were detected by gas-liquid chromatography of a 3 day-old PYG-Tween culture, although the $\mathrm{pH}$ was 5.8 (compared with a $\mathrm{pH}$ of 6.0 in peptoneyeast extract-Tween basal medium), the culture was moderately turbid, and a Gram stain showed many cells. Fermentation acids in a 5-day-old chopped meat-carbohydrate (13) culture were (in millequivalents per $100 \mathrm{ml}$ ): acetic, 1.6; formic, 0.5 ; lactic, 0.3 ; and succinic, 0.1 . Hydrogen gas was not produced.

Some biochemical reactions of ATCC 29799, together with reactions of the species as listed by Tissier (28) and the reactions of 43 other strains tested in our laboratory, are presented in Table 1. In addition, ATCC 29799 converted pyruvate to acetate, but neither threonine nor lactate was utilized. This strain was susceptible to all five antibiotics tested. Approximately onehalf of the other strains of this species that we have tested are resistant to penicillin $G$.

The G+C content of the DNA of ATCC 29799 was $60 \mathrm{~mol} \%$.

Strains of $B$. capillosus have been reported from human feces in a concentration of approximately $10^{9}$ organisms per $\mathrm{g}$ of fecal dry matter, or $0.1 \%$ of the flora $(14,21)$. They have also been isolated from intestinal tracts of mice, hogs, dogs, and termites and from sludge. In addition, they have been found in clinical specimens from abdominal wounds, vaginal drainage, blood, thoracic and brain abscesses, and cutaneous ulcers.

$B$. capillosus can be distingushed from other species in the genus Bacteroides by the follow- ing characteristics (13): colonies on laked BAP have no black pigment; indole is not produced; esculin is hydrolyzed; and carbohydrates are not fermented or are fermented only weakly.

Bacteroides coagulans Eggerth and Gagnon 1933 (6). [Synonyms: Pasteurella coagulans (Eggerth and Gagnon) Prévot 1938 (25); Pseudobacterium coagulans (Eggerth and Gagnon) Krasil'nikov 1949 (18).]

Eggerth and Gagnon in 1933 (6) published a detailed description of an organism which they had isolated from human feces. They named the species Bacteroides coagulans. The original strain has been lost, but the description was sufficiently comprehensive to enable later workers to identify the species with confidence.

ATCC 29798 was selected as the neotype strain of $B$. coagulans since its characteristics are those described by Eggerth and Gagnon for their isolate.

In broth media, cells of ATCC 29798 were small, nonmotile, ovoid rods, 0.8 by 0.8 to 2.4 $\mu \mathrm{m}$, occurring singly, in pairs, or in short chains. They were quite regular in shape, with rounded ends.

Broth cultures were only slightly turbid and had a smooth to ropy sediment. Growth was inhibited by Tween 80 . Since the organism grew appreciably better in an atmosphere of $90 \%$ nitrogen-10\% carbon dioxide than in $100 \%$ carbon dioxide, all broth cultures were inoculated under this combination of gases. The optimum temperature for growth was $37^{\circ} \mathrm{C}$. There was slight turbidity in 1-day-old PYG cultures incubated at 25 and $30^{\circ} \mathrm{C}$; no growth occurred at $45^{\circ} \mathrm{C}$.

Surface colonies on 48-h-old BAP were pinpoint, circular, entire, low convex, transparent, colorless, and smooth. No internal structure was visible.

Biochemical reactions of this strain after 3 days of incubation, reactions of the original isolate described by Eggerth and Gagnon, and reactions of nine other strains tested in our laboratory are listed in Table 1 . The $\mathrm{pH}$ of a 3-dayold PYG culture of ATCC 29798 incubated in a nitrogen-carbon dioxide atmosphere was 6.9 , and that of a 3-day-old culture in basal medium was 7.0. Fermentation acids produced were (in milliequivalents per $100 \mathrm{ml}$ ): acetic, 2.5; formic, 0.2 ; and succinic, 0.2 . Hydrogen gas was not produced. Pyruvate was converted to acetate, but neither lactate nor threonine was utilized. Gelatin was completely liquefied in 8 days. Milk was digested in 3 weeks. Although there was no blackening of SIM medium (BBL Microbiology Systems) from the formation of $\mathrm{H}_{2} \mathrm{~S}$, a strip of filter paper soaked in supersaturated lead acetate solution, dried, and suspended above that medium began to turn black in $24 \mathrm{~h}$. 


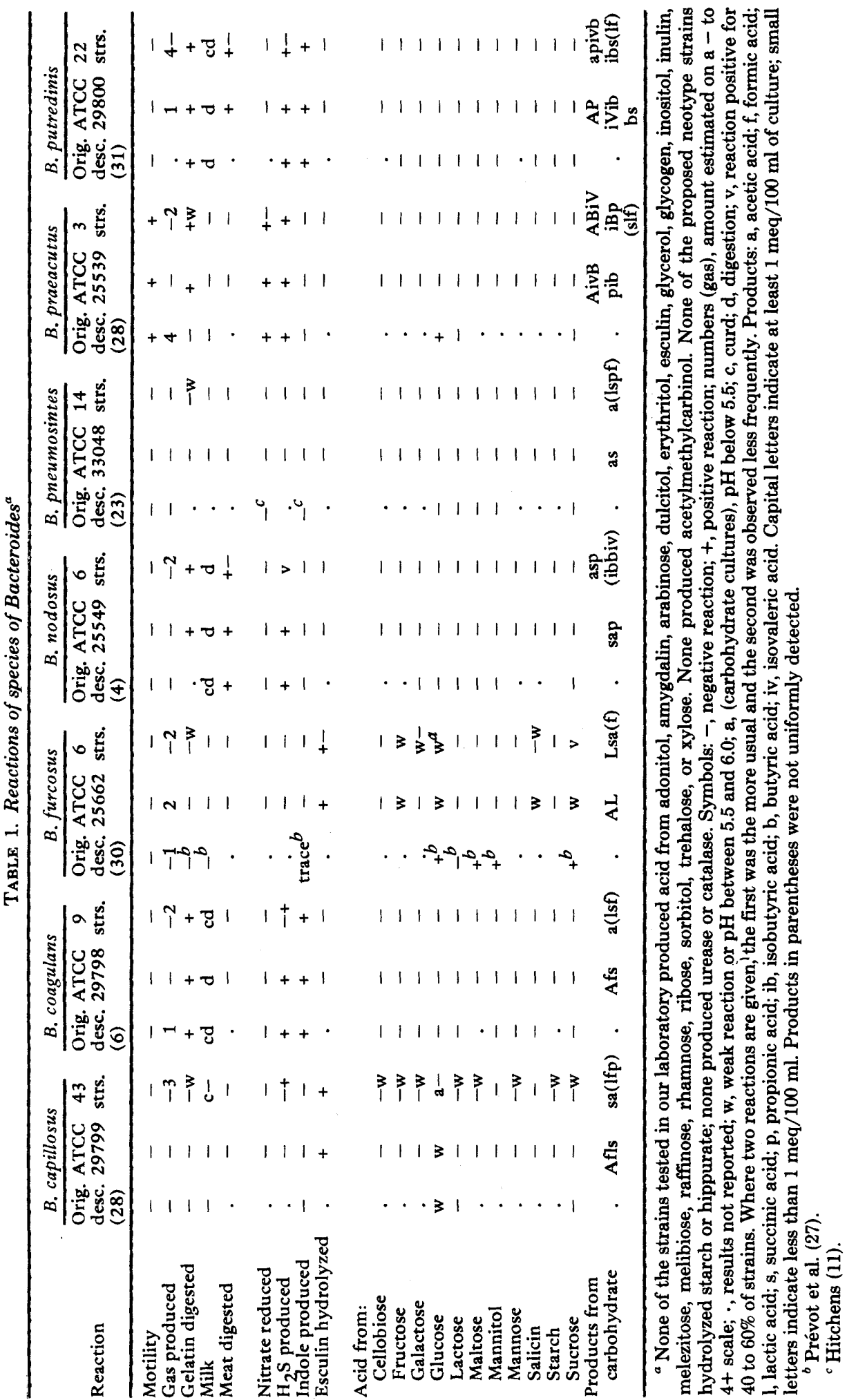


This organism was susceptible to each of the five antibiotics tested.

The $\mathrm{G}+\mathrm{C}$ concent of the DNA of ATCC 29798 was $37 \mathrm{~mol} \%$.

Strains of $B$. coagulans have been isolated from human feces in a concentration of $1.2 \times 10^{8}$ cells per $g$ of feces, or $0.05 \%$ of the flora (14). The organism has also been isolated from clinical specimens taken from lung and urinary tract infections.

$B$. coagulans can be distinguished from other species in the genus Bacteroides by the following characteristics (13): carbohydrates are not fermented; colonies are not pigmented on laked BAP; indole is formed; and acetic acid and any combination of formic, succinic, and lactic acids (in small amounts) are the only fermentation products detected in carbohydrate cultures.

Bacteroides furcosus (Veillon and Zuber) Hauduroy et al. 1937 (9). [Synonyms: Bacillus furocosus Veillon and Zuber 1898 (30); Fusiformis furcosus (Veillon and Zuber) Topley and Wilson 1929 (29); Ristella furcosa (Veillon and Zuber) Prévot 1938 (25); Pseudobacterium furcosum (Veillon and Zuber) Krasil'nikov 1949 (18).]

The first description of this species, published in 1898 by Veillon and Zuber (30), was quite detailed in recording the distinctive pleomorphism of Gram-stained cells and the appearance of surface colonies formed on agar but gave no biochemical reactions. Veillon and Zuber did report that the cells were nonmotile and gram negative and that the organisms produced very little gas.

The original strains, isolated from appendiceal abscesses, were lost, but other strains were later found in pleural abscesses and pulmonary cavities. The description of the species was expanded by Prévot et al. in 1967 (27) after their examination of an isolate from a dental abscess. Characteristics of ATCC 25662 agreed closely with those given in the original and later descriptions $(16,27,30)$, and it is here proposed as the neotype strain.

Cells of ATCC 25662 were short, nonmotile, pleomorphic rods, 0.3 to 1.6 by 2.4 to $4.9 \mu \mathrm{m}$, straight or slightly curved, often with rounded or pear-shaped swellings at the ends. Some appeared to be forked or Y-shaped. They usually occurred singly, but pairs were occasionally seen.

Colonies on anaerobic BAP were pinpoint, circular, low convex, translucent, colorless to gray, smooth, and shiny. No internal structure was seen.

In broth, growth was stimulated by sterile rumen fluid, and this was added to all media to a final concentration of $5 \%$. The optimum temperature for growth was $37^{\circ} \mathrm{C}$, although the or- ganism grew nearly as well at $30^{\circ} \mathrm{C}$. There was slight growth at $25^{\circ} \mathrm{C}$ and none at $45^{\circ} \mathrm{C}$.

Strains of $B$. furcosus may ferment a few carbohydrates, but they do so only weakly. The $\mathrm{pH}$ of a 4-day-old PYG culture of ATCC 25662 was 5.85 , whereas the $\mathrm{pH}$ of a 4-day-old peptoneyeast extract culture was 6.2. Fermentation acids detected in the PYG culture were (in milliequivalents per $100 \mathrm{ml}$ ): acetic, 1.4; and lactic, 0.3 . No hydrogen gas was formed.

Biochemical reactions of ATCC 25662, reactions of the species as described by Veillon and Zuber (30) and emended by Prévot et al. (27), and reactions of six other strains we examined are listed in Table 1. Although Prévot et al. reported that maltose and mannitol were fermented, none of the strains tested in our laboratory fermented these substrates. Neither lactate nor threonine was utilized by the neotype strain, but pyruvate was converted to acetate and lactate. This strain was susceptible to each of the five antibiotics tested.

The G+C content of the DNA of ATCC 25662 was $34 \mathrm{~mol} \%$.

Strains of $B$. furcosus have been isolated from inflamed appendices, lung abscesses, abdominal abscesses, and mud snails. They have been reported from one human fecal sample in a concentration of $3 \times 10^{8}$ organisms per $g$ of dry fecal material, or $0.06 \%$ of the flora (21).

The most distinctive characteristic of $B$. fur. cosus is its pleomorphic morphology showing forked cells.

Bacterodes nodosus (Beveridge) Mráz 1963 (22). [Synonyms: “Organism K" Beveridge 1938 (3); Fusiformis nodosus Beveridge 1941 (4); Ristella nodosa (Beveridge) Prévot 1948 (26).]

Beveridge established in 1941 (4) that the organism he had briefly described as "Organism K" in 1938 (3) was the primary causal agent of infectious foot rot in sheep. He gave an expanded and detailed description of the organism (4) and proposed for it the name Fusiformis nodosus, although he recognized that it had many characteristics of the genus Bacteroides. When distinctions between strains of Bacteroides and Fusiformis (Fusobacterium) became more clear-cut, this organism was transferred to Bacteroides by Mráz (22).

Beveridge did not designate a type strain of the species, but a freeze-dried culture sent by him to L. DS. Smith was studied in our laboratory in 1967 and deposited in the ATCC as a reference strain, ATCC 25549. Since the characteristics of this strain are still those described by Beveridge, we propose that ATCC 25549 be accepted as the neotype strain of $B$. nodosus.

Cells of ATCC 25549 are rather large, nonmotile rods, 1.4 to 1.7 by 3.0 to $12.6 \mu \mathrm{m}$, straight 
or slightly curved, often with swollen ends. They usually occur singly, but occasionally occur in pairs.

Growth was slow on BAP incubated anaerobically. After 6 days, colonies were 1.0 to $3.0 \mathrm{~mm}$ in diameter, circular with a pitted edge, concave, semiopaque, slightly mottled, and white, with a shiny, bumpy surface. Larger colonies had concentric circles with the inner circle pitting the agar. There was no growth on anaerobic egg yolk agar plates.

In broth cultures there was a stringy sediment but no turbidity. The organism grew equally well at 37 and $45^{\circ} \mathrm{C}$, but more slowly at $30^{\circ} \mathrm{C}$. Growth was stimulated by Tween 80 and an atmosphere of $90^{\circ} \mathrm{N}_{2}-10 \% \mathrm{CO}_{2}$. The $\mathrm{pH}$ of a 7 day-old PYG culture was 7.0, and that of a 7day-old peptone-yeast extract culture was 7.2. Fermentation acids detected in the PYG culture (in milliequivalents per $100 \mathrm{ml}$ ) were: acetic, 0.4; propionic, 0.3 ; and succinic, 1.0. No hydrogen gas was formed.

Biochemical reactions of ATCC 25549, reactions of the species as described by Beveridge, and reactions of six other strains we examined are listed in Table 1. In addition, ATCC 25549 converted both lactate and pyruvate to formate and acetate and formed propionate from threonine.

We were unable to obtain enough cells for an accurate determination of the $\mathrm{G}+\mathrm{C}$ content of the DNA of ATCC 25549 , but because its morphology and reactions agree closely with those originally described and because its pedigree is unassailable, we propose that it be accepted as the neotype strain of $B$. nodosus.

The only known habitat of strains of $B$. nodosus is infected hooves of sheep and goats. Although we have strains which have been isolated from human clinical specimens (pilonidal cyst, rectal fistula, decubitus ulcer, and leg wound) and which initially appeared similar to the animal isolate of $B$. nodosus, we feel that these are not members of the species. Four of the human strains were tested by Joseph Gradin, Oregon State University, Corvallis. He found (personal communication) that they were not reactive with fluorescent antibody conjugate from Burroughs Wellcome specific for $B$. nodosus and that their colonial morphology on Eugon agar (BBL Microbiology Systems) with $0.2 \%$ yeast extract and $10 \%$ horse serum was not typical of other strains of the species. Colonies did not grow as readily, nor did they pit the agar beneath. Also, cells of the human strains were shorter and lighter red in Gram strains.

The most useful characteristics in distinguishing $B$. nodosus from other non-saccharolytic Bacteroides species are the following: strongly proteolytic action on gelatin, milk, and meat; indole not produced; nitrate not reduced; and esculin not hydrolyzed (13). Cellular morphology showing blunt clubs or slightly enlarged ends on some cells is also distinctive.

Bacteroides pneumosintes (Olitsky and Gates) Moore and Holdeman 1973 (20). [Synonyms: Bacterium pneumosintes Olitsky and Gates 1921 (23); Dialister pneumosintes (Olitsky and Gates) Bergey et al. 1923 (2); Bacillus pneumosintes (Olitsky and Gates) Ford 1927 (7); Dialister pneumosintes var. septicem. iae Hauduroy et al. 1953 (8).]

In 1921, Olitsky and Gates (23) described organisms they had isolated from nasopharyngeal secretions of pneumonia patients in the early stages of the disease. These organisms were distinctive in that they were small enough to pass through Berkefeld $\mathrm{V}$ and $\mathrm{N}$ filters. When filtrates were injected intratracheally into rabbits, they were pathogenic, visibly affecting only the respiratory organs. Bergey et al. (2) in 1923 created a new genus, Dialister, to accommodate the very tiny gram-negative rods, but since their characteristics in other respects were those of members of the genus Bacteroides, they have been reclassified as Bacteroides pneumosintes by Moore and Holdeman (20).

ATCC 33048, isolated from a nasal abscess, was selected for the neotype strain of $B$. pneumosintes because it has the morphology and reactions first reported by Olitsky and Gates. Cells were so small that some were almost at the visible limit of light microscopy. They were ovals to very short rods with rounded ends, ca. 0.2 to 0.4 by 0.3 to $0.6 \mu \mathrm{m}$, arranged singly, in pairs, or in very short chains.

Colonies on anaerobic BAP were pinpoint, circular, low convex, transparent, colorless, and smooth with no visible internal structure.

Broth cultures were only very lightly turbid even when, by careful examination, many cells could be seen on a Gram stain. There was approximately equal growth at 30 and $37^{\circ} \mathrm{C}$ and no growth at 25 or $45^{\circ} \mathrm{C}$. The $\mathrm{pH}$ of a 7-day-old PYG culture was 6.0. Fermentation acids formed were (in milliequivalents per $100 \mathrm{ml}$ ): acetic, 0.65 ; and succinic, 0.08 . No hydrogen gas was formed. Neither lactate, pyruvate, nor threonine was utilized.

Biochemical reactions of ATCC 33048, reactions given in the original and later descriptions, and reactions of 14 strains we examined in our laboratory are listed in Table 1 . In their first publication, Olitsky and Gates (23) stated that no acid or gas was formed in glucose. They later reported (24) that, after strains had been subcultured several times, cells might be as long as $1.0 \mu \mathrm{m}$, the organisms lost pathogenicity for rab- 
bits, and they now fermented glucose to a final $\mathrm{pH}$ of 5.2 to 5.3. None of the strains we examined fermented glucose even after repeated transfers of the organisms.

We were unable to isolate enough DNA from ATCC 33048 to determine accurately its G+C content.

Strains of $B$. pneumosintes have been isolated from the normal human respiratory flora and from clinical specimens from transtracheal aspirations, sinusitis, vaginal drainage, decubitus ulcers, and jaw and nasal abscesses.

Aside from their general biochemical inertness, the most distinctive characteristic of strains of $B$. pneumosintes is the minute size of their cells.

Bacteroides praeacutus (Tissier) Moore and Holdeman 1973 (20). [Synonyms: Coccobacillus praeacutus Tissier 1908 (28); Zuberella praeacuta (Tissier) Prévot 1938 (25); Fusobacterium praeacutum (Tissier) Hoffman 1957 (12).]

Tissier first isolated these organisms from infant feces and described the species in 1908 (28). ATCC 25539 (= VPI $0563=$ Prévot 3722B) is proposed as the neotype strain of $B$. praeacutus because it has the characteristics described by Tissier (28) and later emended by Beerens and Demonchy (1) and Prévot et al. (27). This strain was isolated from a gangrenous lesion and identified by Prévot as Zuberella praeacuta.

These organisms are motile and peritrichous and occur singly or in pairs. Cells have rounded or occasionally sharply pointed ends. Swellings toward the end of the cell are often seen. Cells of ATCC 25539 were 0.6 to 0.9 by 2.4 to $8.4 \mu \mathrm{m}$. In some strains cells may be as long as $20 \mu \mathrm{m}$.

Surface colonies of ATCC 25539 on 48 -h-old anaerobic BAP were pinpoint, circular, low convex, translucent, colorless, and smooth, with no visible internal structure. They may be $1.0 \mathrm{~mm}$ in diameter in laked blood roll streak tubes.

The organism grew well in peptone-yeast extract basal broth medium. The $\mathrm{pH}$ of a 5-dayold peptone-yeast extract culture was 6.15. PYG cultures were turbid with a smooth sediment. The optimum temperature for growth was $37^{\circ} \mathrm{C}$, although there was moderate turbidity at 25,30 , and $45^{\circ} \mathrm{C}$.

The $\mathrm{pH}$ of a 5-day-old PYG culture was 6.1. Fermentation acids detected in this culture were (in milliequivalents per $100 \mathrm{ml}$ ): acetic, 3.7 ; isovaleric, 1.4; butyric, 1.1; propionic, 0.4 ; and isobutyric, 0.3. Hydrogen gas was not formed.

Biochemical reactions of ATCC 25539, reactions of the species as described by Tissier (28) and as emended by Prévot et al. (27), and reactions of 14 other strains that we examined are listed in Table 1 . In addition, the neotype strain did not utilize pyruvate, lactate, or threonine. It was susceptible to each of the five antibiotics tested.

Tissier stated (28) that the strains on which he based the description of the species produced abundant gas in glucose agar deeps and that they fermented glucose. No strains were available for further study until Beerens and Demonchy (1) isolated from a lung abscess an organism with the characteristics of Tissier's strains, except that gas was not formed and carbohydrate media were not acidified. Examination of this strain made an expanded description of the species possible $(1,27)$. ATCC 25539 was kindly sent to us by A. R. Prévot and identified by him as $Z$. praeacuta, although his record shows that glucose was not fermented. In our laboratory, neither this strain nor any other of the 14 similar strains which we examined fermented glucose or made appreciable amounts of gas. Like many other organisms that utilize peptones rather than carbohydrates, ATCC 25539 completely liquefied gelatin in 8 days. This characteristic appears to be variable among strains, since gelatin was not liquefied by 11 strains which we isolated from human feces.

The G+C content of the DNA of ATCC 25539 was $28 \mathrm{~mol} \%$.

Strains of $B$. praeacutus have been reported from human feces in a concentration of $4.3 \times 10^{8}$ organisms per $\mathrm{g}$ of fecal dry matter, or $0.17 \%$ of the flora (14). They have also been isolated, although rarely, from clinical material from lung abscesses and gangrenous lesions and from blood.

The most useful characteristics of B. praeacutus that distinguish this species from other nonsaccharolytic species in the genus Bacteroides are the following: no pigmentation of colonies on laked BAP; motility; and fermentation products that include butyric, isobutyric, and isovaleric acids (13).

Bacteroides putredinis (Weinberg, Nativelle, and Prévot) Kelly 1957 (17). [Synonyms: "Bacillus A" Heyde 1911 (10); Bacillus putredinis Weinberg et al. 1937 (31); Ristella putredinis (Weinberg et al.) Prévot 1938 (25); Pseudobacterium putredinis (Weinberg et al.) Krasil'nikov 1949 (18)].

Weinberg et al. (31) gave the name Bacillus putredinis to strains reported from infected appendices by Heyde in 1911 (10) and called by him simply "Bacillus A." Together with the name, Weinberg et al. provided the first comprehensive description of the organism. In 1957, the species was transferred to the genus Bacteroides by Kelly (17) as B. putredinis. A human fecal isolate, ATCC 29800 , has the characteristics described by Weinberg et al. (31) for B. putredinis and is here proposed as the neotype strain of this species. 
Cells of ATCC 29800 , after $24 \mathrm{~h}$ of incubation at $37^{\circ} \mathrm{C}$ in PYG broth, were nonmotile, slender rods, straight or slightly curved with rounded ends, usually occurring singly or in pairs, 0.8 to 1.1 by 2.0 to $6.3 \mu \mathrm{m}$. Occasional swellings at one end were seen, but spores were not formed, and the organisms did not survive heating at 70 or $80^{\circ} \mathrm{C}$ for $10 \mathrm{~min}$.

Broth cultures were slightly turbid with a smooth sediment. Growth was slightly stimulated by Tween 80 . The optimum temperature was $37^{\circ} \mathrm{C}$. There was little or no growth at 25 , 30 , or $45^{\circ} \mathrm{C}$.

Colonies on 48-h-old anaerobic BAP were pinpoint, circular to slightly irregular, convex, translucent, colorless to grayish, and smooth with no visible internal structure. Growth was sparse.

Only traces of acid products were detected in a 6-day-old PYG culture, but in 24-h-old chopped meat-carbohydrate culture, the acids detected were (in milliequivalents per $100 \mathrm{ml}$ ): acetic, 0.9 ; propionic, 1.0 ; isobutyric, 0.3 ; butyric, 0.1 ; isovaleric, 1.0; and succinic, 3.9. A large amount of hydrogen gas was produced. The $\mathrm{pH}$ of a 6-day-old PYG culture was 6.2.

Biochemical reactions of ATCC 29800, reactions given by Weinberg et al. for this organism (31), and reactions of 22 other strains we tested are listed in Table 1. Milk cultures were not only digested but also had a putrid odor. $\mathrm{H}_{2} \mathrm{~S}$ was not detected in SIM medium, but a filter paper strip suspended above growth on a slant was blackened, as described previously. Pyruvate was converted to lactate, but neither lactate nor threonine was attacked. This strain was susceptible to the five antibiotics tested.

We were unable to make an accurate determination of the G+C content of the DNA of ATCC 29800 . As has been reported by Werner (33), this strain makes deoxyribonuclease, which may account for the erratic results obtained. We found that the deoxyribonuclease could best be demonstrated when the medium was inoculated under $90 \% \mathrm{~N}_{2}-10 \% \mathrm{CO}_{2}$.

Werner (32) also reported that this strain has a glutamic acid decarboxylase.

Strains of $B$. putredinis have been isolated from inflamed appendices, rectal abscesses, pilonidal and Bartholin cysts, human blood, human and animal feces, sheep foot rot, and farm soil.

B. putredinis can be distinguished from other non-saccharolytic Bacteroides species by its production of indole and of branched-chain volatile fatty acids in broth cultures (13).

\section{ACKNOWLEDGMENTS}

We thank John L. Johnson and Carol Phelps for determinations of the DNA G+C ratios and Susan E. Stevens for excellent technical assistance.
This work was supported by Commonwealth of Virginia project 2002820.

\section{REPRINT REQUESTS}

Address reprint requests to: Elizabeth P. Cato, Anaerobe Laboratory, Virginia Polytechnic Institute and State University, Blacksburg, VA 24061.

\section{ITTERATURE CITED}

1. Beerens, H., and M. Demonchy. 1948. Sur une variété non gazogène de Zuberella praeacuta. C. R. Soc. Biol. 142: $1107-1108$.

2. Bergey, D. H., F. C. Harrison, R. S. Breed, B. $\overline{\mathbf{W}}$. Hammer, and F. M. Huntoon. 1923. Bergey's manual of determinative bacteriology, 1st ed., p. 271-272. The Williams \& Wilkins Co., Baltimore.

3. Beveridge, W. I. B. 1938 . Foot-rot in sheep: a preliminary note on the probable causal agent. J. Counc. Sci. Ind. Res. Aust. 11:1-3.

4. Beveridge, W. I. B. 1941. Foot-rot in sheep: a transmissible disease due to infection with Fusiformis nodosus (n. sp.). Studies on its causes, epidemiology, and control. Counc. Sci. Ind. Res. Aust. Bull. 140:1-56.

5. Castellani, A., and A. H. Chalmers. 1919. Manual of tropical medicine, 3rd ed., p. 959-960. Williams, Wood \& Co., New York.

6. Eggerth, A. H., and B. H. Gagnon. 1933. The bacteroides of human feces. J. Bacteriol. 25:389-413.

7. Ford, W. W. 1927. Textbook of bacteriology, p. 634 . Saunders, Philadelphia.

8. Hauduroy, P., G. Ehringer, G. Guillot, J. Magrou, A. R. Prévot, D. Rosset, and A. Urbain. 1953. Dictionnaire des bactéries pathogènes, 2nd ed., p. 195. Masson and Co., Paris.

9. Hauduroy, P., G. Ehringer, A. Urbain, G. Guillot, and J. Magrou. 1937. Dictionnaire des bactéries pathogènes, p. 61. Masson and Co., Paris.

10. Heyde, M. 1911. Bakteriologische und experimentalle Untersuchen zur Aetiologie Wurmfortsatzentzündung (mit besonderer Berücksichtung der anaeroben Bakterien). Beitr. Klin. Chir. 76:1-136.

11. Hitchens, A. P. 1957. Genus III, Dialister Bergey et al. 1923, p. 440-441. In R. S. Breed, E. G. D. Murray, and N. R. Smith (ed.), Bergey's manual of determinative bacteriology, 7th ed. The Williams \& Wilkins Co., Baltimore.

12. Hoffman, H. 1957. Genus II, Fusobacterium Knorr 1922, p. 436-440. In R. S. Breed, E. G. D. Murray, and N. R. Smith (ed.), Bergey's manual of determinative bacteriology, 7 th ed. The Williams \& Wilkins Co., Baltimore.

13. Holdeman, L. V., E. P. Cato, and W. E. C. Moore (ed.). 1977. Anaerobe laboratory manual, 4th ed. Virginia Polytechnic Institute and State University, Blacksburg.

14. Holdeman, L. V., I. J. Good, and W. E. C. Moore. 1976. Human fecal flora: variation in bacterial composition within individuals and a possible effect of emotional stress. Appl. Environ. Microbiol. 31:359-375.

15. Holdeman, L. V., and J. L. Johnson. 1977. Bacteroides disiens sp. nov, and Bacteroides bivius sp. nov. from human clinical infections. Int. J. Syst. Bacteriol. 27: $337-345$.

16. Holdeman, L. V., and W. E. C. Moore. 1974. Genus I, Bacteriodes Castellani and Chalmers 1919, p. 385-404. In R. E. Buchanan and N. E. Gibbons (ed.), Bergey's manual of determinative bacteriology, 8 th ed. The Williams \& Wilkins Co., Baltimore.

17. Kelly, C. D. 1957. Genus I, Bacteroides Castellani and Chalmers 1919, p. 424-436. In R. S. Breed, E. G. D. Murray, and N. R. Smith (ed.), Bergey's manual of determinative bacteriology, 7 th ed. The Williams \& Wilkins Co., Baltimore.

18. Krasil'nikov, N. A. 1949. Guide to the bacteria and actinomycetes. Akademiya Nauk, SSSR, Moscow. 
19. Marmur, J., and P. Doty. 1962. Determination of the base composition of deoxyribonucleic acid from its thermal denaturation temperature. J. Mol. Biol. 5:109-118.

20. Moore, W. E. C., and L. V. Holdeman. 1973. New names and combinations in the genera Bacteroides Castellani and Chalmers, Fusobacterium Knorr, Eubacterium Prévot, Propionibacterium Orla-Jensen, and Lactobacillus Beijerinck. Int. J. Syst. Bacteriol. 23:6974. (As corrected in Int. J. Syst. Bacteriol. 24:311, 1974.)

21. Moore, W. E. C., and L. V. Holdeman. 1974. Human fecal flora: the normal flora of 20 Japanese-Hawaiians. Appl. Microbiol. 27:961-979.

22. Mráz, O. 1963. Schizomycetes, p. 85. In O. Mráz, J. Tesarčik, and F. Vařejka (ed.), Nomina und Synonyma des pathogenen und saprophytären Mikroben, isoliert aus den wirthschaftlich oder epidemiologisch bedeutenden Wirbeltieren und Lebensmitteln tierisches Herkunft. VEB Gustav Fisher Verlag, Jena.

23. Olitsky, P. K., and F. L. Gates. 1921. Experimental studies of the nasopharyngeal secretions from influenza patients. J. Exp. Med. 33:713-729.

24. Olitsky, P. K., and F. L. Gates. 1922. Experimental studies of the nasopharyngeal secretions from influenza patients. VIII. Further observations on the cultural and morphological characters of Bacterium pneumosintes. J. Exp. Med. 35:813-821.

25. Prévot, A. R. 1938. Études de systématique bactérienne. Ann. Inst. Pasteur Paris 60:285-307.
26. Prévot, A. R. 1948. Manual de classification et de détermination des bactéries anaérobies, 2nd ed. Masson and Co., Paris.

27. Prévot, A. R., A. Turpin, and P. Kaiser. 1967. Les bactéries anaérobies, p. 220. Dunod, Paris.

28. Tissier, H. 1908. Recherches sur la flore intestinale normale des enfants agés d'un an à cinq ans. Ann. Inst. Pasteur Paris 22:189-208.

29. Topley, W. W. W. C., and G. S. Wilson. 1929. The principles of bacteriology and immunity, 1st ed., p. 302. Edward Arnold and Co., London.

30. Veillon, A., and A. Zuber. 1898. Recherches sur quelques microbes strictement anaérobies et leur role en pathologie. Arch. Med. Exp. 10:517-545.

31. Weinberg, M., R. Nativelle, and A. R. Prévot. 1937. Les microbes anaérobies, p. 755. Masson and Co., Paris.

32. Werner, H. 1970. Glutaminsäuredecarboxylaseaktivität bei Bacteroides-Arten. Zentralbl. Bakteriol. Parasitenkd. Infektionskr. Hyg. Abt. 1 Orig. 215:320-326.

33. Werner, H. 1970. Das kulturell-biochemische Verhalten und die Antibiotikaempfindlichkeit des Bacteroides putredinis (Weinberg et al. 1937) Kelly 1957. Zentralbl. Bakteriol. Parasitenkd. Infektionskr. Hyg. Abt. 1 Orig. 215: 327-332.

34. Wilkins, T. D., and T. Thiel. 1973. A modified brothdisk method for testing the antibiotic susceptibility of anaerobic bacteria. Antimicrob. Agents Chemother. 3: 350-356.

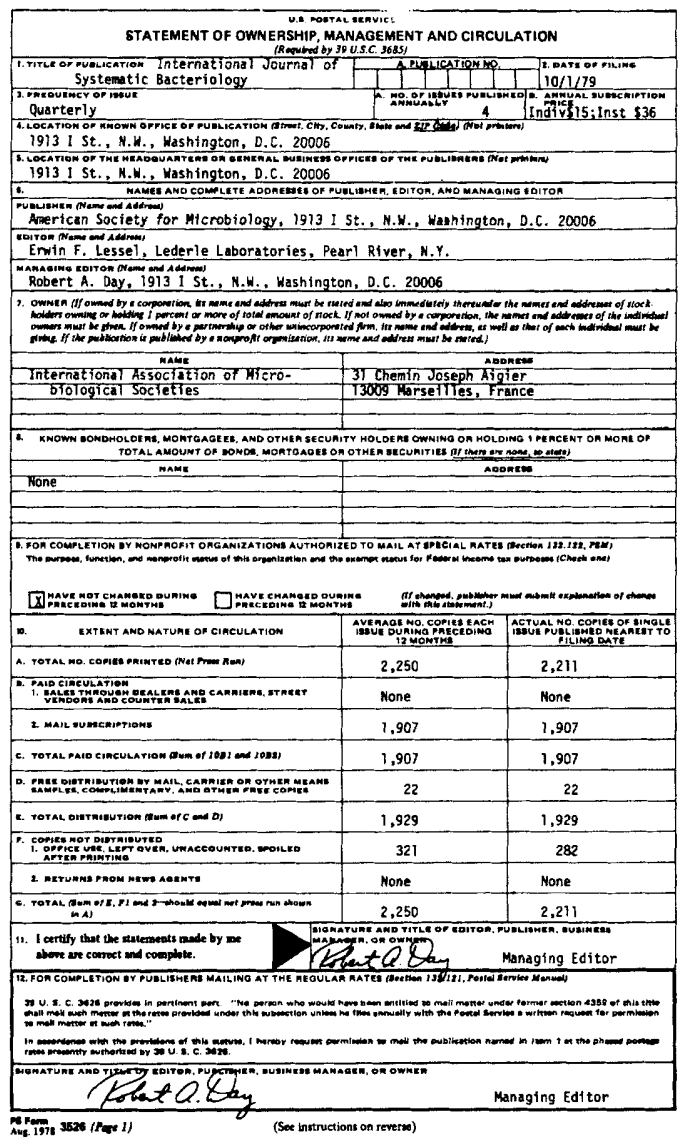

